ophthalmia with well-marked sloughs in both lower fornices. The patient, although there was no apparent urethral discharge, gave a history of gonorrhoea eight years before. The medical officer in charge of the case had the prostate massaged and from the slight mucus discharge obtained the bacteriologist was able to find Gram negative diplococci. He obtained a similar bacillus from the eyes. In this case there had practically never been any discharge from the eyes and the inflammation disappeared without treatment in the course of three or four days. We are convinced that in spite of the bacteriological finding this was an undoubted case of artificial ophthalmia, as the objective signs were very typical. It made us both very sceptical of bacteriological results in eye cases.

In one or two of the cases that had been observed by us, there has been a coincident so-called venereal sore of the penis. We have no doubt that the venereal sores were produced. in the same way as the artificial ophthalmia.

\title{
CATARACT FOLLOWING THYROIDECTOMY
}

BY

H. ROWE JEREMY, LONDON.

CATARACT following experimental thyroidectomy in the dog has been recorded by Mr. Walter Edmunds, ${ }^{1}$ who also cited two cases of cataract following thyroidectomy for enlargement of the gland in the human subject reported by Schiller and Westphal.

So far as I can ascertain no case of cataract following thyroidectomy in the human subject has been recorded in the English literature, and the following case is therefore of some interest.

The patient, Mrs. E. S., aged 50, of Spitalfields, was admitted into the London Hospital on October 29, 1914, with a swelling of the neck, which had first appeared seven weeks previously, and was rapidly increasing in size. A lump was at first noticed on the right side of the neck, but similar swellings had since appeared on the left side. There was pain of a shooting character in the right side of the neck, which radiated down over the right clavicle and shoulder.

Since the swelling in the neck had appeared the patient had suffered from shortness of breath, loss of voice, and cough. There was no history of haemoptysis.

On admission, there was a hard irregular tumour, the size of a hen's egg, in the position of the right lobe of the thyroid gland, and a similar smaller lump in the left lobe. The tumours moved with 
the larynx when the patient swallowed, and were fairly movable on deep structures. The skin was not attached to the lumps.

There were no enlarged glands to be felt in the neck. The larynx was normal, the vocal cords moved freely, and there was no oedema of the arytenoids. The patient had slight dyspnoea, but no dysphagia. An examination of the blood gave a negative Wassermann reaction. The urine was examined and found normal.

On December 9, 1914, the right lobe of the thyroid, the isthmus and part of the left lobe containing the tumours were removed by Mr. Percy Furnivall. The thyroid was difficult to remove, although not materially adherent to surrounding structures. Three enlarged cervical glands were found and removed at the same time. A microscopical examination of the tumour by Dr. H. M. Turnbull showed it to be a solid cuboidal and giant cell medullary carcinoma of the thyroid. The cervical glands were inflamed, but not infected.

Three to four months after the operation her vision began to fail, and she came to the Ophthalmic Department of the London Hospital on March 20, 1915.

The vision in the right eye was then fingers at two feet, and in the left eye, only shadows. Projection of light was good in both eyes.

There was chronic conjunctivitis, but the cornea was bright and clear in both eyes. There was no "keratitis punctata." The pupils were equal, and reacted well to light and accommodation. The irides were greenish in colour, and appeared normal; there were no signs of irido-cyclitis.

The right lens was semi-transparent, and gave a faint red reflex. The details of the fundus were unobtainable. The opacities were of a diffuse punctate character, and showed little striation. The left lens was uniformly opaque; no red reflex was obtained.

The patient was stout, and looked myxoedematous. She was exceedingly feeble, and unable to walk without support. She complained of frequent tetanic spasms in the legs.

Thyroid gland extract in tablet form relieved the symptoms of - tetany, but the patient has become more myxoedematous, and is much weaker.

It is interesting to note the time of onset of the lental opacities. In this case vision began to fail three to four months after the operation. In Schiller's ${ }^{2}$ case the cataracts appeared about six months after the thyroidectomy by Czerny; but in Westphal's ${ }^{3}$ case double cataract was not noted until five and a half years after the operation.

Mr. Percy Dunn ${ }^{4}$ has recently drawn attention to the function of the thyroid gland in controlling toxaemia of septic origin, and attributes many cases of iridocyclitis, interstitial keratitis, and haemorrhages of the conjunctiva and retina to hypo-thyroidism. 
There are no clinical signs of keratitis or iridocyclitis in the above case, but George Coats microscopically examined a dog's eye with cataract after thyroidectomy, for Mr. Walter Edmunds, and reported "a certain amount of infiltration of the ciliary processes, with loosening and tightening of the pigmentation of the outer layer of the epithelium." He also noted that "the aqueous contains a good deal of fibrinous coagulum, perhaps indicating an alteration in composition." In his report, Coats does not describe the condition of the retina and optic nerve, but F. Krauss ${ }^{5}$ recently describes a case in which bilateral choked discs followed thyroidectomy.

Whether the cataract is due to a toxaemia acting on the lens through the ciliary blood-vessels or the aqueous humour, or to general nutritional changes connected with the removal of the thyroid and para-thyroid glands is uncertain, but the balance of evidence seems to point to the cause being a toxaemia uncontrolled by sufficient thyroid and parathyroid secretion.

I am indebted to Colonel W. T. Lister, C.M.G., for his permission to publish this case.

\title{
REFERENCES
}

I. Edmunds; Walter.- "Double cataract following experimental total thyroidectomy in a dog." Proc. of the Roy. Soc. of Med., February, 1916.

2. Schiller, A.-Beitr. z. klin. Chir., J899, Vol. XXIV, p. 586.

3. Westphal, A.-Berl. klin. Wochensihr., August 19, I901, Vol. XXXVIII, No. 33 .

4. Dunn, Percy.-Lancet, 1916, Vol. I. Brit. /l. of Ophthal., January, 1919.

5. Krauss, F.-Med. and Surg. Rep. of the Episcopal Hospital, Philadelphia, Vol. IV.

\section{SOME STATISTICS OF CATARACT EXIRACTION*}

\author{
BY \\ T. HARRISON BUTLER, \\ LEAMINGTON SPA.
}

THE success of an operation for the extraction of senile cataract is apt to be unfavourably influenced by three classes of complications: those which occur at the operation itself; those that supervene during the healing process; and by those which may arise at any period, even years, after a 'successful operation. Finally, disease of the fundus oculi may cause disappointment to both patient and surgeon. Given reasonable skill, careful attention to details, and even moderately docile patients, few cases should be lost on the table, and when such a tragedy occurs, it is almost always the fault of the patient. In my own case, losses in this manner amount to 1.5 per cent. of the total number of operations. We in

\footnotetext{
* Read at the Oxford Ophthalmological Congress, 1918.
} 